\title{
Evaluasi Kesesuaian Lahan Untuk Komoditas Pertanian Di Kecamatan Polombangkeng Utara Kabupaten Takalar
}

\author{
Nurul Fajeriana $M$. \\ Fakultas Pertanian Universitas Muhammadiyah Sorong \\ Nurfariana_miu2@yahoo.co.id
}

\begin{abstract}
Abstrak
Penelitian ini bertujuan mengevaluasi lahan untuk peruntukan komoditas pertanian yang sesuai dengan kondisi biofisik dari lahan yang dimaksud demi mewujudkan pertanian yang berkelanjutan. Penelitian ini dilaksanakan di Kecamatan Polombangkeng Utara Kabupaten Takalar dengan kegiatan survei lapangan dan pengolahan data sekunder serta analisis sifat tanah dilakukan di Laboratorium Kimia Tanah Jurusan Ilmu Tanah Fakultas Pertanian Universitas Hasanuddin berlangsung dari Juli sampai Oktober 2015. Berdasarkan hasil validasi penentuan kelas kesesuaian lahan, maka pola pemanfaatan lahan yang ada di Kecamatan Polombangkeng Utara untuk Tanaman Pangan meliputi: Pertanian sawah, umbi-umbian dan kacang-kacangan disarankan untuk dilakukan penanaman pada Kelurahan Mattompodalle, Kelurahan Malewang, Manongkoki, Panrannuangku, Desa Massamaturu, Timbuseng, Barugayya, Towata, Lassang, Kampung Beru, dan Parang Luara. Sayuran seperti tomat dan cabe pada Deesa Barugayya, Timbuseng, dan Kelurahan Manongkoki. Sedangkan untuk Tanaman Perkebunan yakni: Kapok pada Desa Parang Luara, Towata, Barugayya, Timbuseng; Kelapa pada Desa Timbuseng, Kelurahan Manongkoki, Desa Lassang, Towata, Barugayya; Kopi pada Desa Lassang, Towata, Barugayya, Ko'mara, Timbuseng, Kelurahan Manongkoki; Jambu Mete pada Desa Lassang, Barugayya, Kelurahan Manongkoki; Kakao pada Desa Timbuseng, Towata, Parang Luara; Tebu pada Desa Lassang, Towata, Barugayya, Massamaturu, dan Desa Pa'rappunganta. Tanaman tebu merupakan komoditi unggulan yang ada di Kecamatan Polombangkeng Utara karena di Kecamatan ini telah ada Perkebunan tebu PTPN XIV Pabrik Gula Takalar.
\end{abstract}

Kata kunci: Evaluasi Lahan, Kesesuaian Lahan, Komoditas Pertanian, Takalar.

\section{PENDAHULUAN}

Sektor pertanian merupakan pondasi penting dalam pembangunan nasional, karena menyediakan pangan bagi seluruh penduduk di negeri ini. Semakin bertambahnya penduduk di negeri ini maka kebutuhan akan pangan terus meningkat. Oleh karena itu kebutuhan akan lahan pertanian pun semakin bertambah. Lahan merupakan salah satu jenis sumber daya alam yang relatif tidak terbaharui sehingga harus dimanfaatkan sesuai dengan potensi dan daya dukung yang dimiliki lahan tersebut.

\section{Kesalahan}

merupakan penyebab timbulnya kerusakan lahan dengan istilah lahan kritis yang berdampak pula pada menurunnya produktifitas tanah. Oleh karena itulah dilakukan evaluasi agar pengelolaannya dapat maksimal dan kerusakan lahan dapat diminimalisisir. Evaluasi yang dimaksud yakni evaluasi kesesuaian lahan dimana dilakukan penggambaran tingkat kesesuaian atau kecocokan dari lahan sesuai 
peruntukannya. Selanjutnya Baja (2012) mengemukakan bahwa kesesuaian lahan adalah kecocokan (fitness) suatu jenis lahan untuk penggunaaan tertentu. Kecocokan tersebut dinilai berdasarkan analisis kualitas lahan sehubungan dengan persyaratan suatu jenis penggunaan tertentu, sehingga kualitas yang baik akan memberikan nilai lahan atau kelas yang tinggi terhadap jenis penggunaan tertentu.

Hal ini tidak lepas kaitaannya dengan suatu kawasan atau lingkup wilayah yang merupakan sentra pertanian yakni Kecamatan Polombangkeng Utara yang termasuk salah satu kecamatan yang ada di Kabupaten Takalar dengan kondisi fisik wilayah yang berbukit sampai datar sehingga memberi peluang pengembangan struktur ekonomi di bidang pertanian dan perkebunan.

Produktivitas dari komoditi pertanian tergantung pada kualitas lahan yang digunakan. Oleh karena itu, penentuan jenis komoditinya harus disesuaikan dengan karakteristik lahan.

Berdasarkan uraian tersebut maka dilakukan penelitian untuk mengevaluasi lahan untuk peruntukan komoditas pertanian yang sesuai dengan kondisi biofisik dari lahan yang dimaksud demi mewujudkan pertanian yang berkelanjutan.

\section{METODE PENELITIAN}

\section{Tempat dan Waktu}

Penelitian ini dilaksanakan di

Kecamatan Polombangkeng Utara Kabupaten Takalar dengan kegiatan survei lapangan dan pengolahan data sekunder serta analisis sifat tanah dilakukan di Laboratorium Kimia Tanah Jurusan Ilmu Tanah Fakultas Pertanian Universitas Hasanuddin.

\section{Bahan dan Alat}

Bahan-bahan yang digunakan dalam penelitian ini adalah:

1) Data curah hujan 10 tahun terakhir dari Stasiun Malolo I untuk Kecamatan Polombangkeng Utara.

2) Data-data sekunder berupa data penggunaan lahan dari Badan Pusat Statisik Kabupaten Takalar, 2013.

3) Peta Land System RePPProT (Bakosurtanal 1989),

4) Peta Rupa Bumi skala 1:50.000 (Bakosurtanal,1999),

5) Peta Sebaran Sarana dan Prasarana Kecamatan Polombangkeng Utara (BAPPEDA Kab.Takalar),

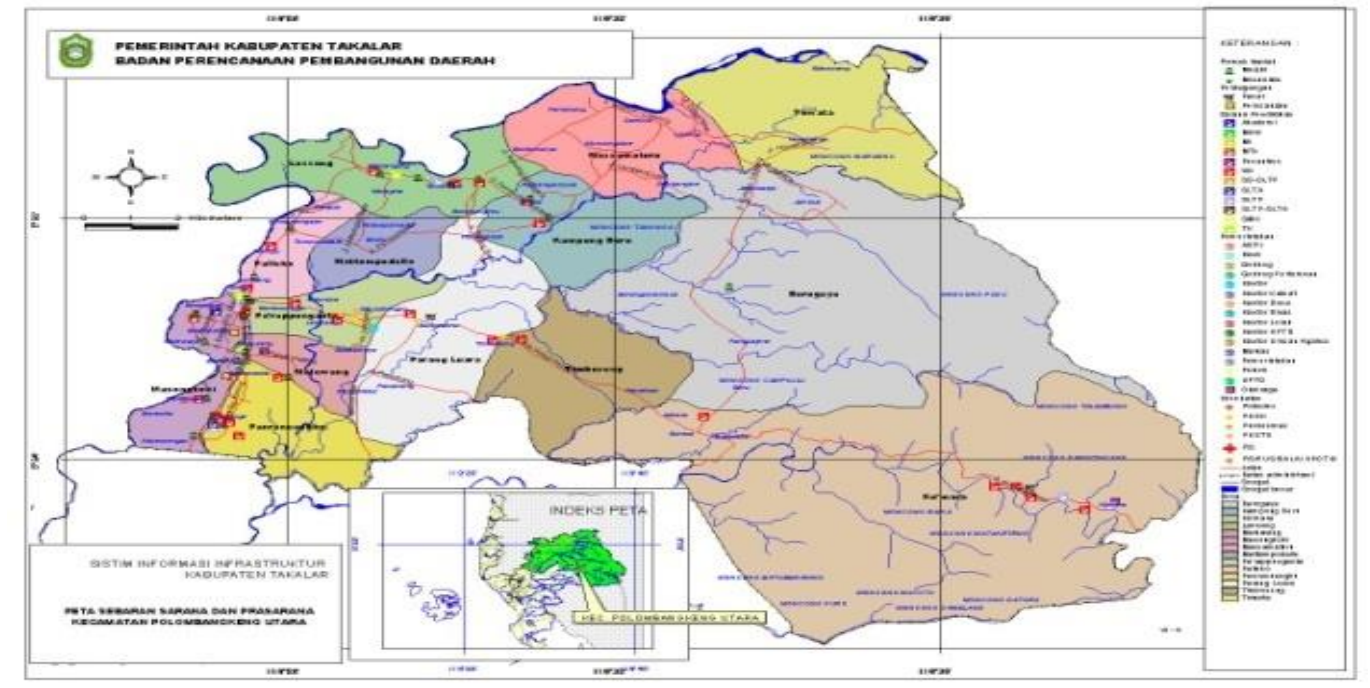


Median Volume X Nomor 1 Bulan Februari 2018

6) Peta Citra Google Earth

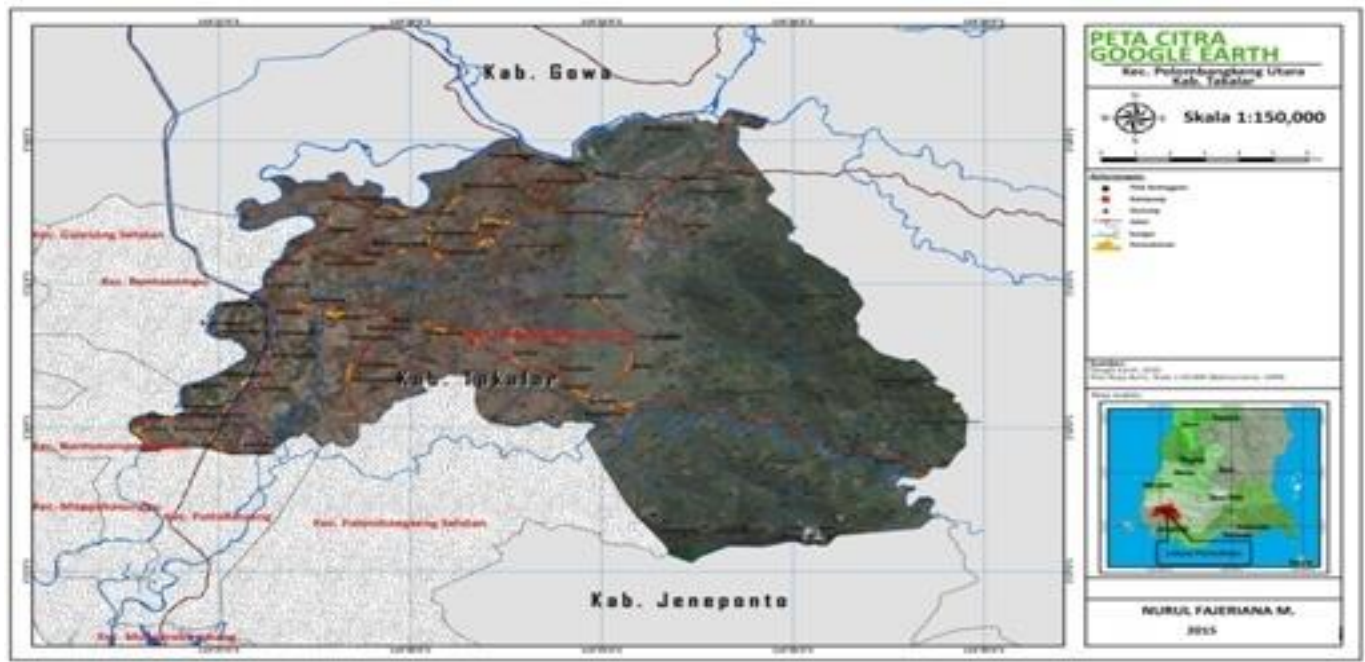

7) Peta Geologi,

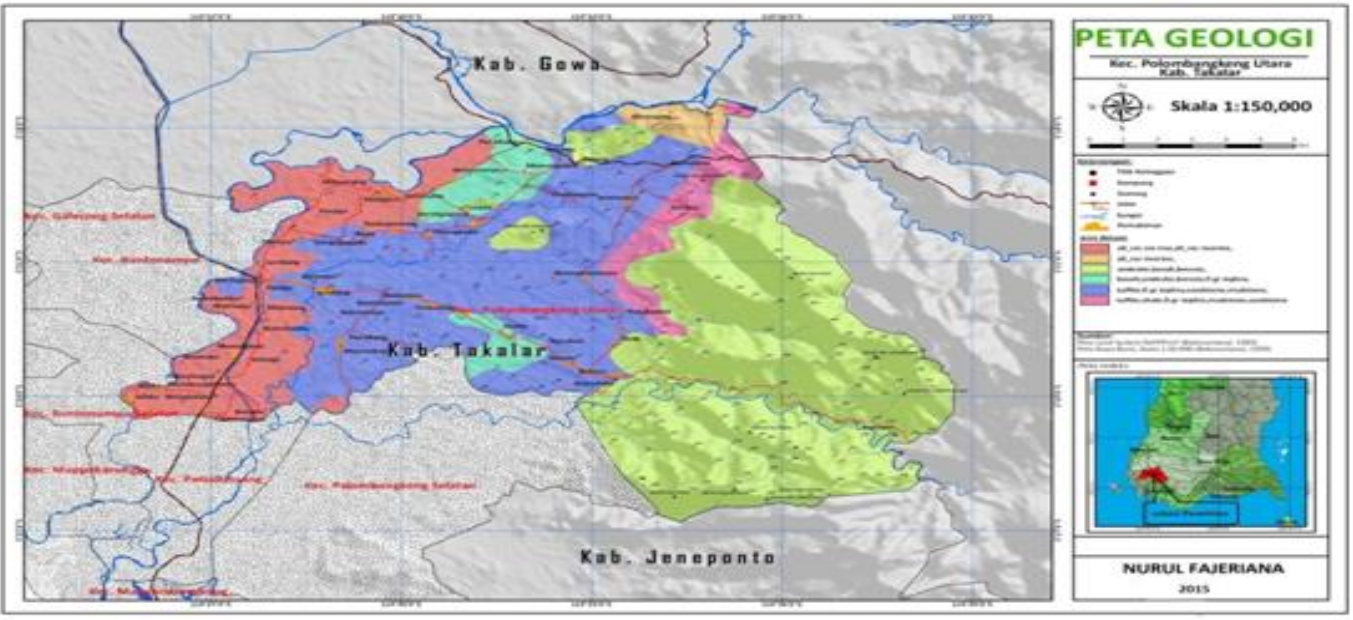

8) Peta Jenis Tanah,

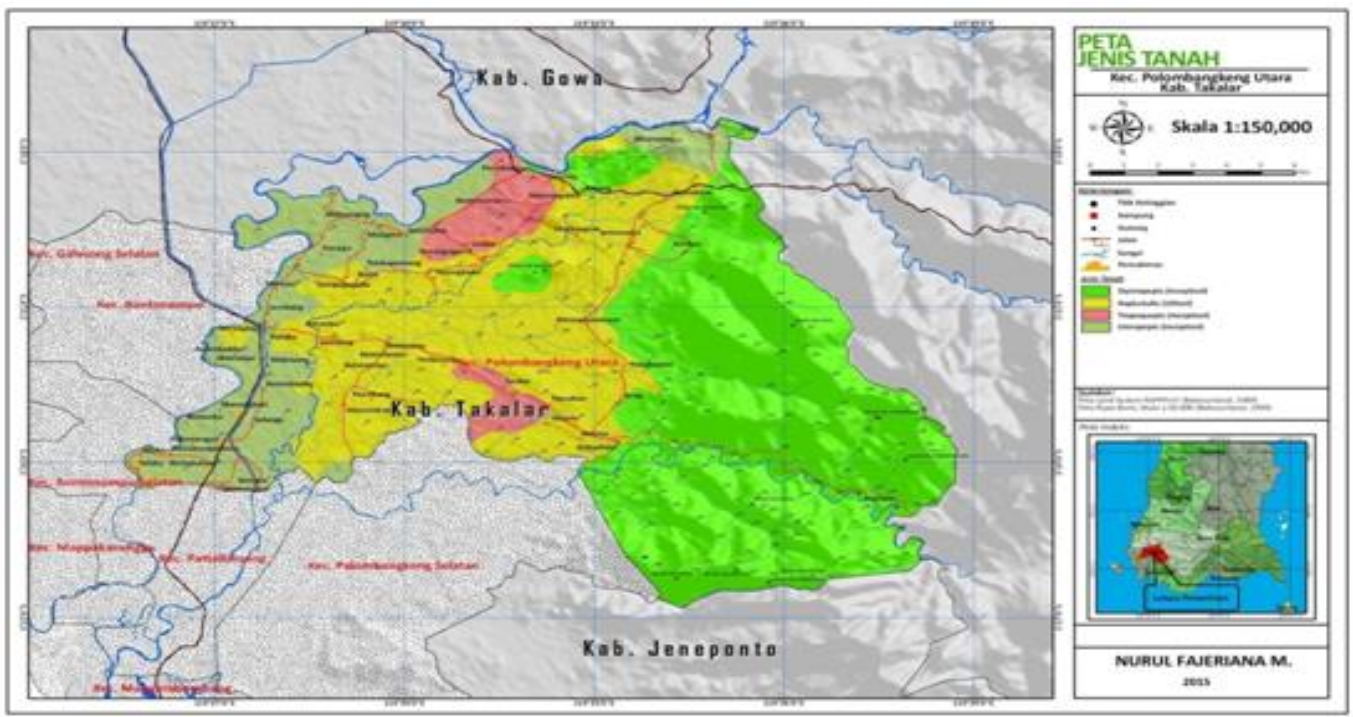




\section{Median Volume X Nomor 1 Bulan Februari 2018}

9) Peta Lereng,

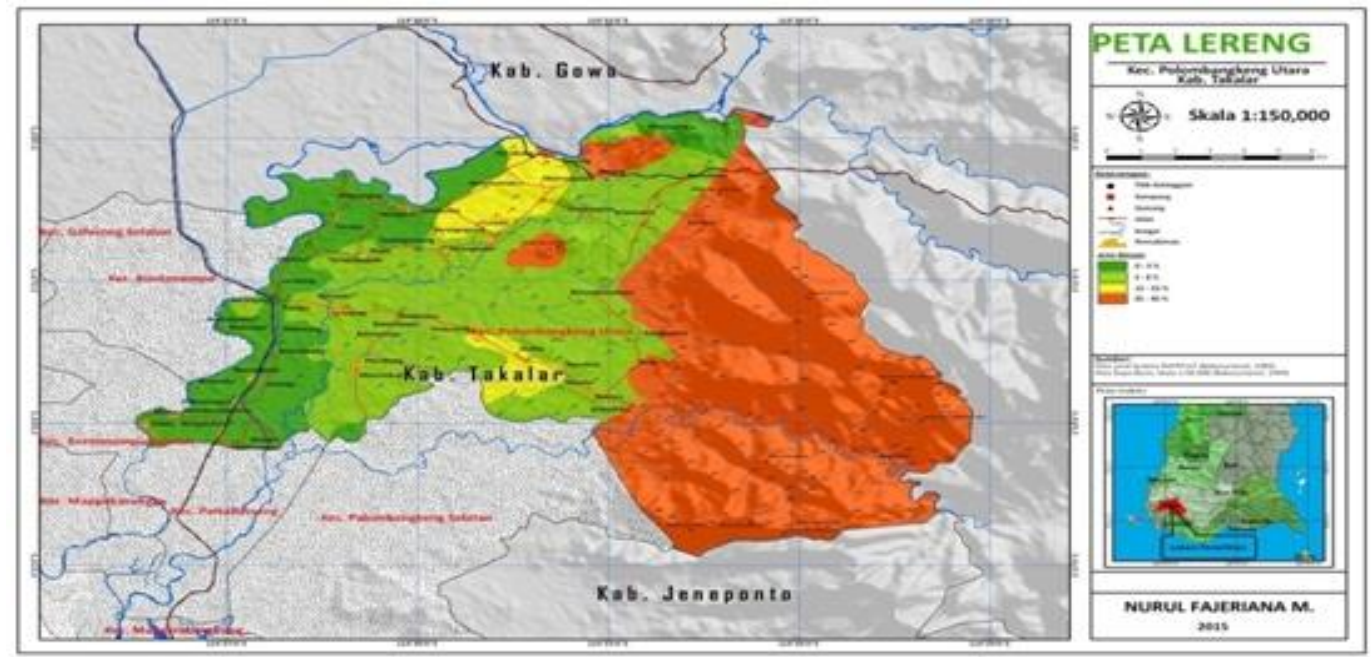

10) Peta Penggunaan Lahan

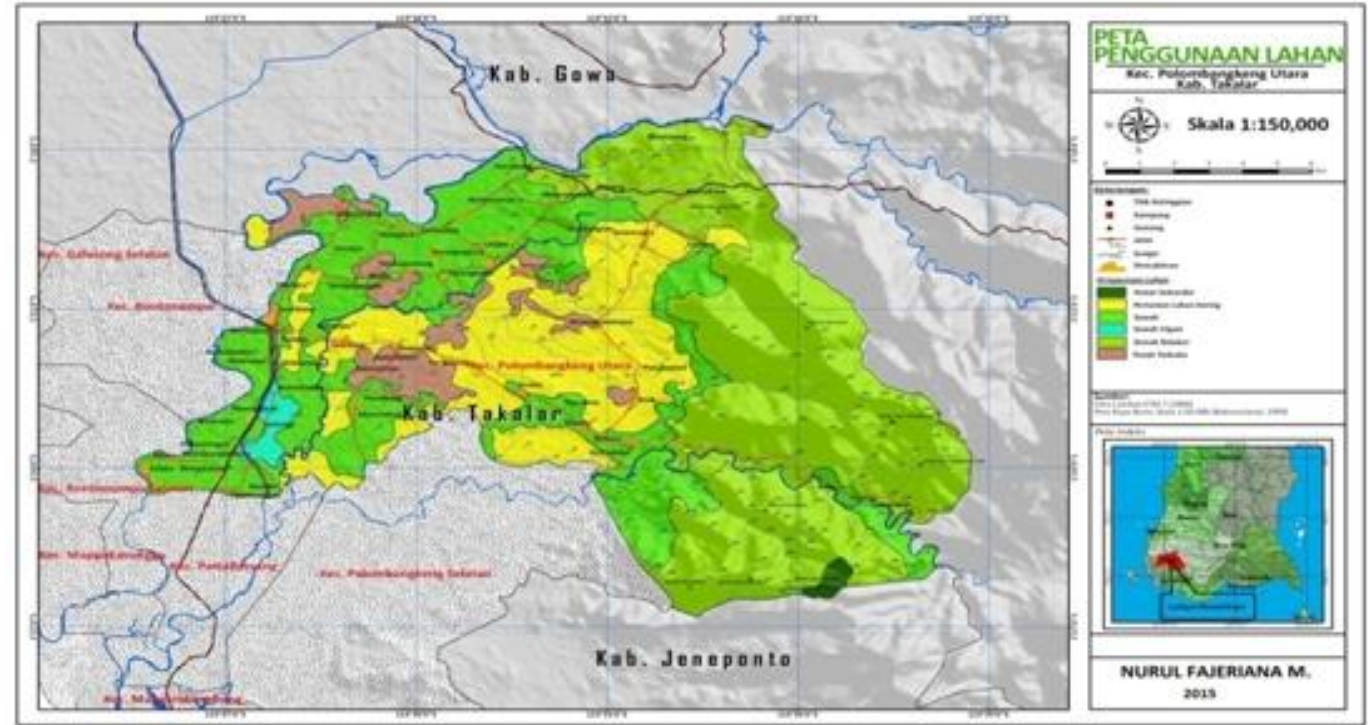

Alat-alat yang digunakan dalam penelitian ini adalah GPS (Global Positioning System), pH meter, kompas, DIP (Daftar Isian Profil), sekop, cangkul, linggis, bor tanah, kantong plastik, kertas label, kamera digital, meteran, cutter, Buku Munsel Soil Color Chart, alat tulis menulis dan seperangkat alat-alat laboratorium.

\section{Tahapan Penelitian}

Tahapan-tahapan penelitian meliputi:

1. Pengolahan data curah hujan yang dihitung dengan cara perhitungan curah hujan rata-rata. Berdasarkan data curah hujan yang ditetapkan dengan tipe iklim menurut klasifikasi Schimdt-Ferguson dan Oldeman. Hasil yang diperoleh kemudian dicocokkan dengan kriteria hujan untuk menentukan bulan basah dan bulan kering, untuk bulan kering (BK) curah hujan rata-rata tahunan $<60$ mm per bulan dan untuk bulan basah (BB) $>100 \mathrm{~mm}$ per bulan.

2. Pembuatan Peta Kerja atau Peta Unit Lahan sebagai acuan dalam pengambilan atau penentuan lokasi 
pengamatan profil tanah. Peta yang dikumpulkan sebelum dioverlay terlebih dahulu diseragamkan skalanya dan skala yang digunakan yakni 1 : 150.000. Peta yang telah dioverlay adalah peta jenis tanah, peta lereng, peta geologi dan peta penggunaan lahan. Dari hasil overlay menghasilkan peta dengan jumlah 18 Unit Lahan yang mewakili 18 profil untuk deskripsi dan analisis lebih lanjut.

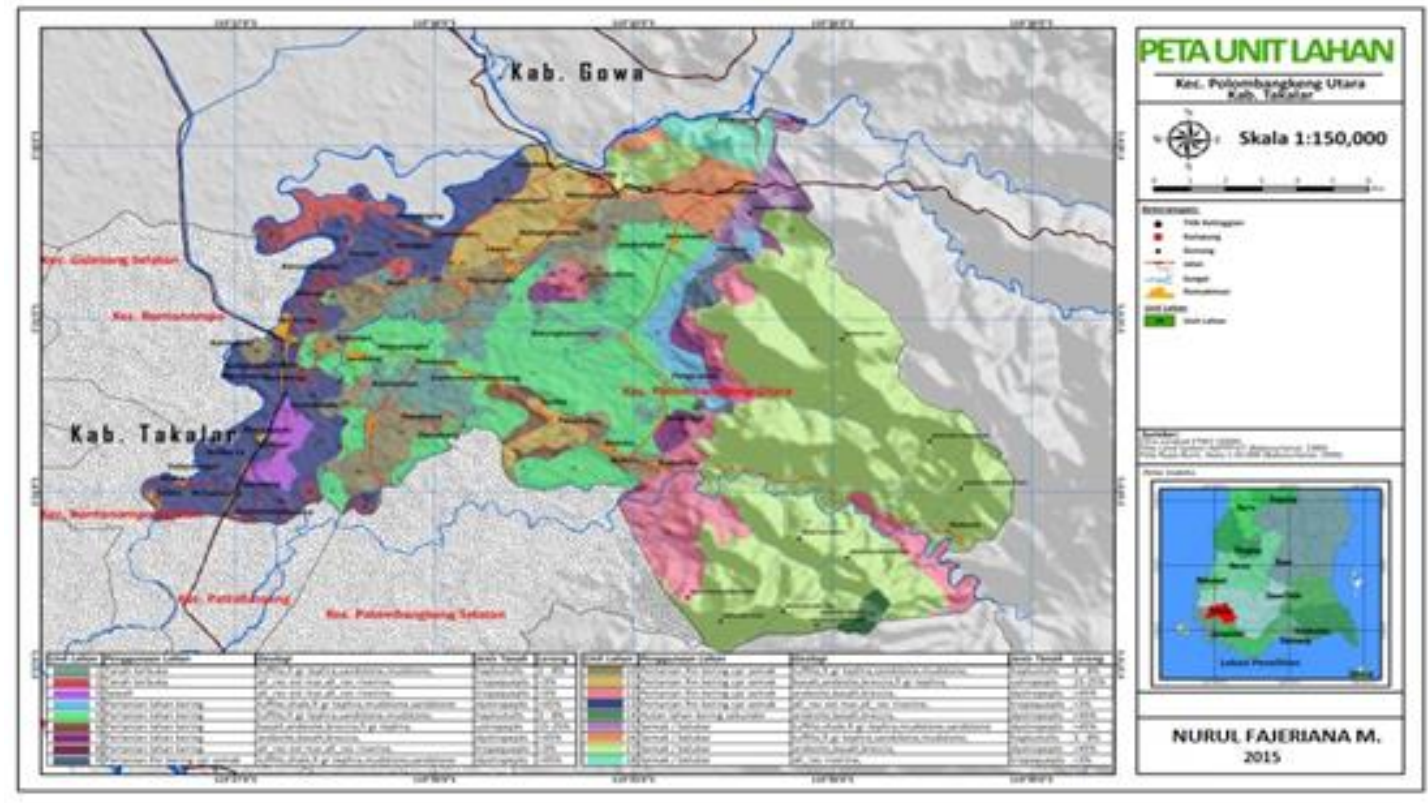

3. Survei lapangan dan pengambilan sampel tanah. Survei ini merupakan survei observasi lapangan dengan menentukan letak dan titik koordinat pengambilan sampel lapangan untuk setiap Unit Lahan. Pengambilan sampel tanah dilakukan pada setiap satuan peta tanah dengan pembuatan profil tanah hingga kedalaman $\pm 130 \mathrm{~cm}$ atau sampai pada lapisan batuan induk apabila tanahnya dangkal. Kemudian masing-masing profil diambil kurang lebih $1 \mathrm{~kg}$ tanah yang nantinya akan dianalisis untuk analisis sifat kimia tanah. Setelah itu dilakukan pengamatan profil dan hasilnya dituliskan dalam daftar isian profil (DIP). Selain itu dilakukan juga pengamatan lokasi meliputi bentuk wilayah, vegetasi, kondisi drainase tanah, kedalaman tanah, tingkat bahaya banjir, struktur tanah, tekstur tanah, konsistensi tanah, batas antar lapisan, kondisi batuan dipermukaan dan tingkat erosi.

4. Analisis tanah di laboratorium untuk penetapan sifat kimia tanah, maka digunakan sampel tanah sebanyak \pm 1 $\mathrm{kg} / \mathrm{sampel}$ tanah. Sampel tanah yang telah tersedia terlebih dahulu dikering udarakan kemudian dianalisis disesuaikan dengan informasi yang diperlukan untuk penilaian lahan. Analisis contoh tanah dilakukan di laboratorium yang meliputi:

a) Kapasitas Tukar Kation (KTK) ditetapkan dengan penjenuhan NH4OAc.

b) Kemasaman tanah $(\mathrm{pH}) \quad\left(\mathrm{H}_{2} \mathrm{O}\right.$ $1: 2,5)$ dengan $\mathrm{pH}$ meter.

c) $\mathrm{C}$ - organik dengan metode Walkley dan Black.

d) $\mathrm{P}_{2} \mathrm{O}_{5}$ tersedia dalam ppm dengan metode Bray I.

e) N Total, dengan metode Kjeldhahl. 


\section{Median Volume X Nomor 1 Bulan Februari 2018}

5. Penentuan kelas kesesuaian lahan. Berdasarkan data iklim, hasil pengamatan dilapangan dan sifat kimia tanah, maka ditetapkan kelas kesesuaian lahan untuk tiap komoditi pertanian. Parameter yang diamati kemudian dicocokkan dengan kriteria klasifikasi kesesuaian lahan baik sifat fisik maupun kimianya yang dijabarkan dalam kesesuaian lahan aktual dan potensial. Penentuan kelas kesesuaian lahan aktual ditentukan pada tingkat sub kelas. Kesesuaian lahan dibuat berdasarkan klasifikasi kesesuaian lahan Second Land Resource and Planning Project (LREP II) yang mengacu pada Framework of Land Evaluation (FAO, 1976).

\section{KEADAAN UMUM WILAYAH}

\section{Orientasi Wilayah, Letak Geografis \& Batas Administrasi}

Lokasi penelitian ini dilaksanakan di Kecamatan Polombangkeng Utara yang merupakan kecamatan dengan luas wilayah yang paling luas diantara kecamatan lain yang ada di Kabupaten Takalar. Luas wilayah Kecamatan Polombangkeng Utara 212,25 $\mathrm{km}^{2}$. Ibukota dari Kecamatan Polombangkeng Utara yakni Palleko yang memiliki jarak dari ibukota Kabupaten ke Ibukota Kecamatan yakni $9 \mathrm{~km}$. Kecamatan Polombangkeng Utara memiliki 6 kelurahan yang terdiri dari 9 desa, 68 dusun, 142 rukun warga, dan 281 rukun tetangga.

Secara geografis Kecamatan Polombangkeng Utara terletak pada koordinat 5 $5^{\circ} 18^{\prime} 0^{\prime \prime}$ - 5 5 27'0" LS dan $119^{\circ} 26^{\prime} 0$ "' - 119³9'0”'BT.

Adapun batas administrasi Kecamatan Polombangkeng Utara adalah sebagai berikut :
a. Sebelah Utara berbatasan dengan Kabupaten Gowa.
b. Sebelah Timur berbatasan dengan Kabupaten Gowa.

c. Sebelah Selatan berbatasn dengan Kecamatan Polombangkeng Selatan dan Kecamatan Pattalassang.

d. Sebelah Barat berbetasan dengan Kecamatan Bontonompo Kabupaten Gowa.

\section{Iklim}

Berdasarkan data curah hujan selama 10 tahun terakhir di daerah penelitian yang bersumber dari stasiun penakar curah hujan Malolo I diperoleh data bahwa berdasarkan klasifikasi iklim menurut Oldeman daerah tersebut digolongkan daerah dengan tipe iklim pertanian $\mathrm{C}_{2}$ yakni pada umumnya hanya dapat ditanami padi satu kali dan palawija satu kali, meskipun masih ada peluang menanam palawija satu kali lagi, tetapi disesuaikan kebutuhan airnya.

Dan untuk Sistem Klasifikasi Schmidt-Ferguson termasuk dalam tipe iklim C dimana daerahnya agak basah dengan ciri vegetasi hutan rimba, diantara jenis vegetasi yang gugur daunnya pada musim kemarau diantaranya jati.

\section{Jenis Tanah}

Berdasarkan data yang diperoleh dari peta jenis tanah Kecamatan Polombangkeng Utara Kabupaten Takalar, maka jenis tanah yang terdapat pada daerah penelitian terdiri dari jenis tanah Inceptisol (Dystropepts, Ustropepts, dan Tropaquepts) yang merupakan tanah muda, tetapi lebih berkembang daripada Entisol dan umumnya mempunyai horison kambik dan tanah Ultisol (Haplustuls) yang merupakan tanah-tanah dengan akumulasi (penimbunan) liat di horison bawah (horison argilik), bersifat masam, kejenuhan basa (jumlah kation) pada kedalaman $180 \mathrm{~cm}$ dari permukaan tanah kurang dari $35 \%$.

\section{Kelerengan}

Secara umum sebagian besar daerah penelitian mempunyai tingkat kelerengan yang berbeda. Dari data yang disajikan dalam bentuk peta lereng Kecamatan 


\section{Median Volume X Nomor 1 Bulan Februari 2018}

Polombangkeng Utara Kabupaten Takalar terlihat bahwa sebagian daerah penelitian berada pada kelas kelerengan $0-3 \%$ dengan luas 3960 ha. Kelas kelerengan 3 $8 \%$ dengan luas 6972 ha, kelas kelerengan $15-25 \%$ dengan luas 798 ha, dan kelas kelerengan > 45\% memiliki luas 9495 ha.

\section{Geologi}

Keadaan geologi Kecamatan Polombangkeng Utara Kabupaten Takalar secara umum termasuk dalam golongan stadium dewasa dengan tekstur permukaan halus. Endapan Aluvium terdiri dari lempung, pasir, lumpur, kerikil, dan bongkah batuan yang tidak padu (lepas). Endapan ini berasal dari hasil desentegrasi batuan yang tidak padu (lepas).

\section{Hidrologi}

Pada umumnya terdiri atas sungai besar dengan sejumlah anak sungai yang memiliki anak-anak sungai sehingga membentuk percabangan seperti pohon. Sungai yang terdapat di Kecamatan Polombangkeng Utara adalah sungai Jenemaeja, sungai Pamukulu, sungai Lantang, dan sungai Papa. Hampir semua dasar sungai ini terdiri batu dan kerikil.

Debit air sungai sangat dipengaruhi oleh hujan. Pada saat musim kemarau, sungai-sungai kecil tidak mempunyai aliran air walaupun masih terdapat genangan. Sungai yang masih mengalir pada musim kemarau adalah sungai Pa'ppa dan sungai Jeneberang. Pada saat musim hujan antara bulan November sampai dengan Mei, sungai di wilayah ini sering mengalami banjir.

Disebelah barat PG.Takalar terdapat Waduk Balang Ilalang seluas empat hektar yang digunakan sebagai kolam stabilisasi limbah pabrik. Air buangan dari waduk ini juga dimanfaatkan untuk mengairi sawah penduduk. Potensi sumber air untuk keperluan air bersih maupun irigasi diairi irigasi Bili-Bili sungai Jene'berang Kabupaten gowa dan bendungan Pamukkulu.

\section{Penggunaan Lahan dan Vegetasi}

Kecamatan Polombangkeng Utara memiliki luas lahan 21225 ha yang terdiri atas luas sawah irigasi 9463,61 ha, hutan sekunder 102,5 ha, pertanian lahan kering 4070,2 ha, semak belukar 7212,8 ha, tanah terbuka 121,7 ha, luas pemukiman 45,5 ha, dan luas sungai (tubuh air) 207,98 ha.

Adapun data penggunaan lahan untuk pertanian di Kecamatan Polombangkeng Utara adalah tanaman pangan dan perkebunan dapat dilihat pada tabel berikut :

Tabel 1. Luas panen dan jumlah produksi tanaman pangan di Kecamatan Polombangkeng Utara.

\begin{tabular}{clcc}
\hline No. & Tanaman & Luas (ha) & $\begin{array}{c}\text { Produksi } \\
\text { (ton) }\end{array}$ \\
\hline 1. & Padi Sawah & $5.502,71$ & $31.939,84$ \\
2. & Jagung & 590 & $2.684,5$ \\
3. & Ubi Kayu & 208,13 & $3.896,19$ \\
4. & Ubi Jalar & 182,48 & $6.147,75$ \\
5. & Kacang & 59,18 & 63,32 \\
6. & Tanah & 115,41 & 807,87 \\
7. & Cabe & 19,72 & 167,62 \\
\hline
\end{tabular}

Sumber: Badan Pusat Statistik Kabupaten Takalar Tahun 2013.

Sedangkan Luas areal dan Jumlah Produksi Tanaman Perkebunan Rakyat menurut jenisnya, yakni:

Tabel 2. Luas panen dan jumlah produksi $\begin{array}{lr}\text { Tanaman } & \text { Perkebunan di } \\ \text { Kecamatan } & \text { Polombangkeng } \\ \text { Utara. } & \end{array}$

\begin{tabular}{llcc}
\hline No. & Tanaman & Luas (ha) & $\begin{array}{c}\text { Produksi } \\
\text { (ton) }\end{array}$ \\
\hline 1. & Kapok & 196 & 100 \\
2. & Kelapa & 202,5 & 124,5 \\
3. & Kopi & 8 & 4,4 \\
4. & Jambu Mete & 1.016 & 530 \\
5. & Kakao & 23 & 9 \\
6. & Tebu & 685,59 & 29,779 \\
\hline
\end{tabular}

Sumber: Badan Pusat Statistik Kabupaten Takalar Tahun 2013. 


\section{Median Volume X Nomor 1 Bulan Februari 2018}

\section{HASIL DAN PEMBAHASAN}

\section{Penilaian Keseuaian Lahan}

Berdasarkan hasil analisa kelas kesesuaian lahan yang dilakukan telah ditentukan penilaian kelas kesesuaian lahan baik kelas kesesuaian lahan aktual maupun potensial. Djaenudin, $d k k$. (2003) menyatakan bahwa kelas kesesuaian lahan pada kondisi aktual menyatakan kesesuaian lahan berdasarkan data dari hasil survei tanah atau sumber daya lahan belum mempertimbangkan masukanmasukan yang diperlukan untuk mengatasi kendala atau faktor pembatas yang berupa sifat fisik lingkungan termasuk sifat-sifat tanahdalam hubungannnya dengan persyaratan tumbuh tanamanyang dievaluasi. Sedangkan kesesuaian lahan potensial menyatakan keadaan lahan yang akan dicapai apabila dilakukan usahausaha perbaikan (improvement).

Analisa kesesuaian lahan untuk setiap jenis komoditi disajikan dalam tabel lampiran 1 untuk tanaman pangan dan tabel lampiran 2 untuk tanaman perkebunan. Analisa tersebut dilakukan untuk setiap jenis komoditi yang ada.

Faktor pembatas unsur hara $\mathrm{P}$ $\left(\mathrm{P}_{2} \mathrm{O}_{5}\right)$, C-organik, dan $\mathrm{N}$-totalserta daya menahan unsur hara ( $\mathrm{pH}$ tanah dan KTK), dapat diatasi dengan pemberian pupuk dan pengapuran sehingga peningkatan kelas kesesuaian lahan potensial dapat diperoleh. Sedangkan untuk kualitas/karakteristik lahan dapat dilakukan perbaikan dengan menaikkan kelas kesesuaian lahan aktual menjadi kelas kesesuaian lahan potensial setingkat lebih tinggi dengan menggunakan modal sedang hingga tinggi. Penentuan kelas kesesuaian lahan untuk komoditas tanaman dibahas berdasarkan unit lahan tersebut. Menurut Hardjowigeno (2007) bahwa faktor pembatas dapat dibedakan menjadi dua jenis, yaitu (1) faktor pembatas yang sifatnya permanen dan tidak mungkin atau tidak ekonomis untuk diperbaiki, dan (2) faktor pembatas yang dapat diperbaiki dan secara ekonomis masih mengutungkan dengan memasukkan teknologi yang tepat.

\section{Tanaman Pangan}

Penilaian kelas kesesuaian lahan untuk tanaman pangan dilakukan untuk 7 jenis komoditi yakni padi, jagung, ubi kayu, ubi jalar, kacang tanah, tomat, dan cabe.

Tanaman pangan pada dasarnya adalah tanaman yang tumbuh dalam waktu musiman, ditanam dengan jangka waktu tertentu serta memerlukan perawatan yang khusus seperti dalam proses pemupukan dan penggunaan pestisida.

Berdasarkan pertimbangan tersebut yang divalidasi dengan hasil penentuan kelas kesesuaian lahan, maka pola pemanfaatan lahan yang ada di Kecamatan Polombangkeng Utara meliputi:

1. Pertanian sawah, umbi-umbian dan kacang-kacangan disarankan pada Kelurahan Mattompodalle, Kelurahan Malewang, Manongkoki, Panrannuangku, Desa Massamaturu, Timbuseng, Barugayya, Towata, Lassang, Kampung Beru, dan Parang Luara.

2. Sayuran seperti tomat dan cabe pada Desa Barugayya, Timbuseng, dan Kelurahan Manongkoki.

\section{Tanaman Perkebunan}

Tanaman perkebunan yang diusahakan oleh penduduk di Kecamatan Polombangkeng Utara terdiri dari 6 jenis komoditi antara lain kapok, kelapa, kopi, jambu mete, kakao, dan tebu.

Adapun hasil penentuan kelas kesesuaian lahan untuk masing-masing jenis tanaman tersebut disajikan dalam lampiran tabel 2.

Sedangkan untuk tanaman perkebunan lainnya yang juga ditanam oleh petani di Kecamatan Polombangkeng Utara seperti:

a. Kapok pada Desa Parang Luara, Towata, Barugayya, Timbuseng 


\section{Median Volume X Nomor 1 Bulan Februari 2018}

b. Kelapa pada Desa Timbuseng, Kelurahan Manongkoki, Desa Lassang, Towata, Barugayya,

c. Kopi pada Desa Lassang, Towata, Barugayya, Ko'mara, Timbuseng, Kelurahan Manongkoki.

d. Jambu Mete pada Desa Lassang, Barugayya, Kelurahan Manongkoki.

e. Kakao pada Desa Timbuseng, Towata, Parang Luara.

f. Tebu pada Desa Lassang, Towata, Barugayya, Massamaturu, dan Desa Pa'rappunganta. Tanaman tebu merupakan komoditi unggulan yang ada di Kecamatan Polombangkeng Utara karena di Kecamatan ini telah ada Perkebunan tebu PTPN XIV Pabrik Gula Takalar.

\section{Kesimpulan}

Berdasarkan hasil penelitian yang Polombangkeng Utara maka dapat disimpulkan bahwa jenis komoditi yang potensial dikembangkan di Kecamatan Polombangkeng Utara untuk masing- masing komoditi disesuaikan berdasarkan analisis kelas kesesuaian lahan.

\section{DAFTAR PUSTAKA}

Baja Sumbangan, Prof. 2012. Perencanaan Tata Guna Lahan dalam Pengembangan WilayahPendekatan Spasial dan Aplikasinya. Penerbit Andi. Yogayakarta.

BPS, 2013. Kabupaten Takalar Dalam Angka. Badan Pusat Statistik Kabupaten Takalar.

Djaenuddin D., H. Marwan., Subagyo H. dan A.Hidayat. 2003. Petunjuk Teknis Evaluasi Lahan Untuk Komoditas Pertanian. Balai Penelitian Tanah, Puslitbangtanak. Badan Penelitian dan Pengembangan Pertanian. Bogor.

Hardjowigeno Sarwono dan Widiatmaka. 2007. Evaluasi Kesesuaian Lahan dan Perencanaan Tataguna Lahan. Gadjah Mada University Press, Yogyakarta. 